Apidologie, 1980, 11 (4), 367-374.

\title{
RELATIONSHIPS BETWEEN CONSUMPTION OF A POLLEN SUPPLEMENT, HONEY PRODUCTION AND BROODREARING IN COLONIES OF HONEYBEES APIS MELLIFERA L. II
}

\author{
Keith M. DOULL'
}

\section{SUMMARY}

During a year-long field test of a commercial pollen supplement, its consumption did not influence broodrearing in colonies that received the supplement during a "pollen deficient" honeyflow from Eucalyptus leucoxylon. Nevertheless productivity in these colonies at $63.782 \mathrm{~kg}$ of honey per colony and $1.04 \mathrm{~g}$ of honey per bee was significantly higher than the $25.513 \mathrm{~kg}$ per colony and $0.44 \mathrm{~g}$ of honey per bee in colonies that did not receive the supplement.

Failure of the supplement to influence broodrearing is ascribed to its low protein and high sugar content when compared with stored pollen on a Total Food basis and to the fact that it did not present the specific stimuli that elicit the pollen-feeding behaviour pattern in nurse bees.

Its influence on productivity is thought to have been due to the fact that bees that consumed the supplement had higher body protein at the onset of foraging. Since the nectar of E. leucoxylon probably contains minimal amounts of pollen, bees foraging for nectar did not obtain adventitious protein from pollen filtered out of the nectar in their honey stomachs. With higher initial levels of body protein, foragers from the Treatment colonies would have had longer lifespans and so would have been more productive than bees from the Control colonies.

The implications of these findings for future research on the development and use of artificial diets for honeybees are discussed.

\section{INTRODUCTION}

The first paper in this series examined relationships between consumption of a commercial pollen supplement, honey production and broodrearing in honeybee colonies in a year-long field test of the supplement (Doull, in press).

1. Honorary Visiting Research Fellow, Department of Entomology, Waite Agricultural Research Institute, The Universityof Adelaide, Glen Osmond South Australia. 
Floral conditions varied from time to time during the year as the hives were moved to different sites to take advantage of a succession of honeyflows. In spring the hives were in an apiary where S. A. Bluegum, Eucalyptus leucoxylon provided a " pollen deficient " honeyflow.

Results for this period have been analysed to examine the effects of the supplement on the performance of the colonies in these particular floral conditions.

\section{METHODS}

The methods used in this experiment were described in the previous paper.

Eucalyptus leucoxylon is one of several species of the genus Eucalyptus that are major sources of nectar for honeybees but from which bees do not usually gather pollen. Beekeepers describe these species as providing " pollen deficient " honeyflows and honey production in these conditions is regulated by the amount and quality of pollen that the bees can collect from alternative sources.

During the period under discussion native shrubs and ground flora provided pollen. Only limited amounts of pollen were available in early September but the amounts collected by the bees increased steadily and all colonies were able to maintain reasonable reserves of pollen for most of the period. These alternative sources of pollen produced only minimal amounts of nectar.

\section{RESULTS}

The results for the period are presented in Table 1 which shows means per colony for broodrearing, honey production and stored pollen in the Treatment and Control colonies.

TABL. 1. - Relationships between the consumption of a commercial pollen supplement and honey production in honeybees colonies during a pollen deficient honeyflow.

\begin{tabular}{l|c|c|c}
\hline \hline & $\begin{array}{c}\text { Treatment } \\
\text { Colonies }\end{array}$ & $\begin{array}{c}\text { Control } \\
\text { Colonies }\end{array}$ & $\begin{array}{c}\text { L.S.D. } \\
P=0.05\end{array}$ \\
\hline No. of bees reared & 61650 & 57132 & N.S. \\
Honey/colony $(\mathrm{kg})$ & 63.782 & 25.513 & 24.52 \\
Honey/bee $(\mathrm{g})$ & 1.04 & 0.44 & .41 \\
Area of stored pollen $\left(\mathrm{dcm}^{2}\right)$ & 144.99 & 67.89 & 11.18 \\
Supplement consumed $(\mathrm{mg} / \mathrm{bee})$ & 29.7 & - & - \\
\hline \hline
\end{tabular}

Consumption of the supplement did not influence broodrearing in the Treatment colonies and although these colonies maintained significantly greater reserves of stored pollen it would seem that the availability of pollen was not a factor limiting broodrearing in any of the colonies. But consumption of the supplement had a significant influence on productivity in the Treatment colonies. 


\section{DISCUSSION}

The pollen supplement does not appear to have made any major contribution to the nutrition of the larvae in the Treatment colonies.

HAYDAK (1935) estimated that $3.21 \mathrm{mg}$ of nitrogen is required to rear a single bee from hatching to emergence and this may be obtained from $100 \mathrm{mg}$ of pollen. Pollen is also consumed by newly emerged bees to obtain the nutrients that are essential for the development of the hypopharyngeal glands and other body tissues and the secretions of these glands while providing the protein component of the food of the larvae are also the food of the queen bee during oviposition and of adult drones.

So ALFonsus (1933) found that a colony consumed $145 \mathrm{mg}$ of pollen for every bee reared in his test colonies while Rosov (1944) calculated that $120 \mathrm{mg}$ of pollen and $142 \mathrm{mg}$ of honey were consumed for every bee reared in his colonies.

In this experiment $30.2 \mathrm{mg}$ of the supplement were consumed for every bee reared over the whole year, while during the period discussed in this paper an average of 29.2 $\mathrm{mg}$ of pollen supplement were consumed for every bee reared in the Treatment colonies.

So it is clear that the supplement made little if any contribution to the nutrition of the larvae in these colonies.

The supplement did not present the specific stimuli that elicit the pollen feeding behaviour pattern (Doull, 1980) but even if it had done so its composition was such that the bees could not have consumed enough of it to obtain all the essential nutrients they required for the secretion of larval food.

DETHIER (1976) pointed out that in insects that have a source of food continuously available, the pattern of feeding is " regulated by simple physics. They may feed until it is impossible for them to cram in any more food and a second meal is not possible until room becomes available in the alimentary canal of more food $"$.

Consequently the presentation of analyses of artificial foods for bees on a Total Food basis rather than on the conventional Dry Matter basis is a more accurate method of assessing their true nutritional value.

Stored pollen - the natural protein food of the honeybee - contains, on average, 23.3 \% Crude Protein, $\mathbf{3 0 . 4} \%$ total sugars and $\mathbf{2 3 . 8} \%$ moisture on a Total Food basis (Herbert et al., 1977). The artificial food contained $18 \%$ Crude Protein and $56 \%$ sugars on the same basis - an analysis which is similar to artifical diets recommended by Doull (1977) and StaNdifer et al., (1978).

This low level of protein along with the high sugar content of the supplement and its lack' of the specific phagostimulants must have meant that it was not an acceptable food for young adult bees and nurse bees. They would probably feed on pollen to obtain the proteins and other essential nutrients they required and would have obtained additional sugars by feeding on honey in cells in the brood combs. 
But pollen supplements are consumed most readily when placed close to the brood area (Doull, et al., 1966; Doull, 1977) so it is apparent that it is consumed mainly by bees in this area. Although the peak of pollen consumption occurs in bees up to the age of 10-12 days, bees that are past the broodrearing phase of adult life still retain the ability to respond to the feeding stimuli presented by pollen. Their ability to respond to these stimuli declines until at age 18-20 days they no longer feed on pollen. As their requirements for pollen decline so their requirements for sugars increase. These bees continue to carry out many activities associated with the broodnest and so would be likely to come in contact with a pollen supplement placed directly above the brood cluster. They would respond to the sugars it contained and, as was pointed out in the previous paper, would thereby obtain additional protein so that with higher body protein at the onset of foraging their vigour, longevity and honey production would be enhanced.

But productivity per bee in both Treatment and Control colonies during this period was substantially below that for the whole year and this decline in productivity per bee may be ascribed to another aspect of the nutrition of adult bees and to specific characteristics of the nectar of $E$. leucoxylon.

While bees are foraging for nectar any pollen grains that are present in the nectar are filtered out of the crop by the action of the proventriculus and are passed back to the ventriculus (BAILEY, 1952). Although it is generally assumed that foraging bees have limited ability to digest pollen, de Groot (1953) showed that such bees are able to digest and metabolise proteins with beneficial effects on their longevity. In addition bees that are engaged in ripening honey will also obtain pollen through the action of the proventriculus as will all bees that feed on honey that contains pollen.

In foragers this adventitious pollen that is removed from nectar as they forage must reduce the rate of depletion of body protein and must enhance their longevity and potential productivity. ToDD and VANSELl (1942) found that the pollen content of nectars collected by bees ranged from zero in the case of nectar from Navel orange Citrus sinensis to a maximum of $103.33 \times 10^{3}$ grains $/ \mathrm{ml}$ in nectar from Brassica alba.

There is no information on the pollen content of Bluegum nectar but indirect evidence suggests that the flowers may produce comparatively small amounts of pollen.

This was shown in an experiment with colonies on a Bluegum honeyflow in which a pollen trap yielded only $40 \mathrm{~g}$ of pollen a day (PURDIE and Doull, 1964). Despite the fact that the colonies were rearing brood and that alternative sources of pollen were scarce only $1.8 \%$ of this pollen was from the Eucalypt. Yet the bees foraged actively on Bluegum and $45.8 \mathrm{~kg}$ of honey were extracted from the Control colonies during the first 40 days of the experiment.

PARKER (1925) found that about $17 \%$ of bees foraging primarily for nectar may return to the hive carrying nectar and pollen obtained from the flowers they have visited so that had the bees been able to collect pollen from the Bluegum, a higher proportion of the pollen in the pollen trap should have come from the Bluegum flowers. 
A proportion of the staminal filaments of the flowers of E. leucoxylon do not bear anthers and since bees seeking nectar must crawl over or through the anthers to reach the nectar, the small proportion of Eucalyptus pollen in the pollen trap suggests that the remaining anthers may produce comparatively small amounts of pollen. Consequently it is likely that the nectar of $E$. leucoxylon contains feww pollen grains. grains.

Assuming this to be so, the effect of the pollen supplement on productivity may be explained in terms of its influence on body protein at the onset of foraging. Foragers would have obtained minimal amounts of adventitious pollen from the nectar they collected and body protein would have been depleted at the same rate in bees from both Treatment and Control colonies. But bees in the Treatment colonies would have obtained additional protein in the pollen supplement they consumed in response to its high content of sugars. As a result body protein at the onset of foraging would have been higher in these bees than in bees from the Control colonies. Their lifespan as foragers would then have been longer and their productivity higher.

This hypothesis gains some support from the results during the final period of this experiment when River Red Gum E. camaldulensis was the main nectar source. Bees collect abundant nectar and pollen from this species and a pollen trap yielded $1.6 \mathrm{~kg}$ of Red Gum pollen in one day. Many bees collected both nectar and pollen from Red Gum flowers and productivity was $4.1 \mathrm{~g}$ and $3.8 \mathrm{~g} /$ honey bee in the Treatment and Control colonies respectively.

Detailed studies under controlled conditions are needed to test the validity of this hypothesis. If proven correct, it suggests further studies of artificial diets to be used according to floral conditions.

Where artificial diets are required to enable colonies to initiate or maintain broodrearing when pollen is scarce, a complete artificial diet approximating in its composition to that of stored pollen on a Total Food basis, and containing phagostimulant chemicals to elicit the pollen-feeding behaviour pattern will be needed.

But if pollen supplies are adequate to maintain broodrearing, and the nectar the bees collect is deficient in pollen - as for example that from Navel Orange - then a sugar candy containing 10-20\% Crude Protein should enhance productivity per bee and per colony.

\section{ACKNOWLEDGEMENTS}

The late Professor M. H. HAYDAK assisted in the laboratory studies that led to the development of the pollen supplement and in the planning and early stages of the experiment. Mr. K. C. CELLIER carried out the statistical analysis of the original results and Dr. P. W. MILES provided helpful and constructive criticism of the two papers. 
The original study was supported in part by a grant trom the Australian Honey Research Advisory Committee.

Received for publications in July 1980.

\begin{abstract}
RESUME
RELATIONS ENTRE LA CONSOMMATION D'UN COMPLEMENT DE POLLEN, LA PRODUCTION DE MIEL ET L'ELEVAGE DU COUVAIN PAR DES COLONIES D'ABEILLES, APIS MELLIFERA L. II
\end{abstract}

Eucalyptus leucoxylon est l'une des espèces d'eucalyptus qui constituent les principales sources de nectar pour les abeilles, mais sur lesquelles les butineuses récoltent peu ou pas de pollen. La production de miel provenant de ces espèces est donc régie par la disponibilité de pollen venant d'autres sources.

Au cours d'un test d'un complément commercial de pollen qui dura un an, E. leucoxylon a fourni la majeure partie du nectar récolté par les abeilles. Les arbustes et la flore au sol ont fourni le pollen nécessaire à l'élevage du couvain. Dans ces conditions le complément de pollen n'a pas influencé l'élevage et, puisque $29,7 \mathrm{mg}$ seulement de complément ont été consommés par chacune des abeilles élevées dans les colonies testées, la consommation du complément n'a pas pu contribuer de façon importante à la nutrition des larves des colonies testées.

La productivité de ces colonies a pourtant été de $63,782 \mathrm{~kg}$ de miel par colonie et de $1,4 \mathrm{~g}$ de miel par abeille, tandis que dans les colonies témoins elle était respectivement de $25,513 \mathrm{~kg}$ et $0,44 \mathrm{~g}$.

L'absence d'influence du supplément de pollen sur la nutrition des larves a été due à sa composition déséquilibrée du point de vue nutritif, comparée à celle du pollen stocké. L'alimentation des abeilles et d'autres insectes est régie par des mécanismes physiques simples : ils se nourrissent jusqu'à ce que le tube digestif soit plein et ne s'alimenteront à nouveau que lorsque suffisamment de nourriture aura été digérée et que de la place aura ainsi été faite. La relation entre la valeur nutritive et le volume de nourriture est donc importante car si la nourriture est trop volumineuse ou si les proportions des principales substances nutritives sont mal équilibrées, les abeilles ne seront pas capables de consommer assez de nourriture pour satisfaire tous leurs besoins alimentaires. La composition des aliments protéiniques artificiels pour abeilles doit donc ressembler à celle du pollen stocké, du point de vue de la nourriture totale plutôt que la matière sèche.

De ce point de vue le complément de pollen était fortement déficient en protéines et contenait presque deux fois plus de sucre que le pollen stocké.

Le pollen stocké contient aussi des substances chimiques qui déclenchent le comportement d'alimentation sur pollen chez les abeilles récemment écloses et chez les nourrices. Ces abeilles se nourrissent de pollen pour obtenir les substances nutritives nécessaires à la sécrétion de nourriture larvaire. Si elles s'étaient nourries de complément de pollen, elles auraient consommé juste assez pour satisfaire leurs besoins en sucre.

On suggère que le complément de pollen a été consommé pour les ouvrières chargées des travaux intérieurs et âgées de 12-18 jours, attirées par la forte teneur en sucres du produit. Ce faisant, elles auraient reçu des protéines supplémentaires, si bien que leur teneur corporelle en protéines au début du butinage aurait été plus élevée que celle des abeilles des colonies témoins.

Le nectar d'E. leucoxylon contient probalement peu de pollen, si bien que les butineuses n'auraient pas reçu les protéines accessoires qu'elles obtiennent normalement du pollen filtré à travers leur jabot. Les butineuses des deux groupes auraient supporté les mêmes taux de déplétion des protéines corporelles, mais puisque les abeilles qui avaient consommé le complément de pollen avaient une teneur plus forte en protéines au début du butinage, leur longévité et donc leur productivité auraient été accrues. 
On suggère que, si des expériences plus précises prouvent la validité de cette hypothèse, un pain de sucre contenant $20 \%$ de protẹines serait susceptible d'améliorer la productivité d'abeilles qui récoltent des nectars pauvres en pollen.

\section{ZUSAMMENFASSUNG}

\section{BEZIEHUNGEN ZWISCHEN DEM VERBRAUCH EINES POLLENERSATZMITTELS, DEM HONIGERTRAG UND DER BRUTAUFZUCHT IN VÖLKERN DER HONIGBIENE, A. MELLIFERA L., II}

Eucalyptus leucoxylon (Südaustralischer Bluegum) ist einer von mehreren Eukalyptusarten, die für die Bienen eine Haupttracht an Nektar, aber nur wenig oder gar keinen Pollen liefern. Die Honigproduktion von diesen Arten wird deshalb von der Pollenmenge begrenzt, die von anderen Pflanzen zur Verfügung steht.

Während einer Periode eines sich über ein ganzes Jahr erstreckenden Feldversuches mit einem kommerziellen Pollenersatzmittel lieferte E. leucoxylon den Grossteil des von den Bienen gesammelten Nektars, während Sträucher und Bodenflora genügend Pollen zur Aufrechterhaltung der Bruttätigkeit lieferte. Unter diesen Bedingungen beeinflusst der Pollenersatz die Bruttätigkeit nicht, und da jede Biene, die in den Versuchsvölkern aufgezogen wurde, nur $29,7 \mathrm{mg}$ des Ersatzmittels verbrauchte, konnte der Verzehr des Ersatzmittels keinen wesentlichen Beitrag zur Ernährung der Larven in den Versuchsvölkern geleistet haben.

Dennoch belief sich der Ertrag in diesen Völkern auf $63,782 \mathrm{~kg}$ Honig je Volk und auf $1,04 \mathrm{~g}$ Honig je Biene, im Vergleich zu $25,513 \mathrm{~kg}$ Honig je Volk und $0,44 \mathrm{~g}$ Honig je Biene in den Kontrollvölkern.

Das Fehlen eines Einflusses des Ersatzmittels auf die Larvenernährung war auf seinen unbalancierten Gehalt an Nährstoffen im Vergleich zu dem eingelagerten Pollen zurückzuführen. Die Nahrungsaufnahme der Honigbienen und anderen Insekten wird durch einfache physikalische Vorgänge reguliert, in dem sie fressen bis der Verdauungskanal gefüllt ist, und sie keine neue Nahrung zu sich nehmen, bis genug verdaut ist, um für neue Nahrung Raum zu bieten. Daher ist das Verhältnis zwischen Nährstoffgehalt und der Masse der aufgenommenen Nahrung von Bedeutung, denn wenn das Volumen der Nahrung zu gross ist oder wenn das Verhältnis der Hauptnährstoffe unbalanciert ist, wird die Biene nicht im Stande sein, genug Nahrung aufzunehmen, um ihren Bedarf zu decken. Deshalb sollte die Zusammensetzung eines künstlichen Proteinfutters der von eingelagertem Pollen entsprechen, und zwar auf Basis der Gesamtmenge und nicht auf der Basis des Trockengewichtes. Auf dieser Basis hatte das Pollenersatzmittel einen hohen Mangel an Protein und es enthielt beinahe die doppelte Zuckermenge des eingelagerten Pollens.

Eingelagerter Pollen enthält ausserdem Stoffe, die das Verhaltensmuster der Pollenaufnahme bei frisch geschlüpften und bei Pflegebienen auslöst, und diese Bienen hätten dann Pollen verzehrt und damit die essentiellen Nährstoffe für die Ausscheidung von Futtersaft erhalten. Wenn sie aber Ersatzstoffe aufnehmen, dann haben sie nur soviel verzehrt, dass ihr Zuckerbedarf gedeckt ist.

Es wird vermutet, dass das Pollenersatzmittel von 12-18 Tagen alten Stockbienen wegen seines hohen Zuckergehaltes aufgenommen wurde. Dabei hätten sie gleichzeitig zusätzlich Eiweiss erhalten, so dass bei Beginn der Sammeltätigkeit ihr Proteingehalt höher war als bei den Kontrollvölkern.

Der Nektar von E. leucoxylon enthält wahrscheinlich nur wenig Pollen, so dass Trachtbienen kein zusätzliches Protein erhalten, das sie normalerweise durch den aus der Honigblase herausgefilterten Pollen gewinnen. Trachtbienen würden in beiden Gruppen an Proteinmangel leiden, aber die Bienen mit der Ersatznahrung würden bei Beginn der Trachtzeit einen hohen Gehalt an Körperprotein aufweisen, wodurch ihre Langlebigkeit und damit auch ihre Produktivität gesteigert würde.

Es wird vermutet - vorausgesetzt, diese Hypothese kann durch weitere präzise Experimente gestützt werden - dass ein Zuckerteig mit einem Zusatz von $20 \%$ Protein die Produktivität von Bienen erhöhen könnte, die Nektar mit einem niedrigen Pollengehalt sammeln. 


\section{REFERENCES}

Alfonsus A., 1933. - Zum Pollenverbrauch des Bienenvolkes. Arch. für Bienenkunde 14 : 220-233.

BaILEY L. E., 1952. - The action of the proventriculus of the honeybee Apis mellifera.J. Exp. Biol. 29 : 310-327.

Dethier V. C., 1976. - « The Hungry Fly ». Harvard University Press.

Doull K. M., 1977a. - " Supplementary Feeding of Honeybees ». Beekeeping Technology and Equipment Standing Commission, Apimondia Tech. Recom. 5-v-4.

Doull K. M., 1977b. - Tucson pollen supplements. A m. Bee J. 177 : 296-297.

Doull K. M., 1980a. - "The Nutrition of Honeybees » in Biennial Report Waite Agricultural Research Institute 1978-1979 (in press).

DoulL K. M., 1980b. - Relationships between consumption of a pollen supplement, honey production and broodrearing in colonies of honeybees Apis mellifera (in press).

Doull K. M., Purdie J..D. and Haydak M. H., 1966. - Krawaite, The Waite Institute pollen supplement. A ust. Beekeeper 66 : 301-308.

Groot A. P. de, 1953. - Amino acid requirements of honeybees. Phys. Comp. et Oecol. : 3 : 1-90.

Herbert E. W. Jr., Shimanuki H. and Caron Dewey, 1977. - Caged honeybees (Hymenoptera, Apidae) : Comparative value of some proteins for initiating and maintaining broodrearing by bees. Apidologie $8: 229-235$.

Parker, Ralph L., 1925. - The Collection And Utilization Of Pollen By The Honeybee. Cornell Agr. Exp. Sta. Memoir 98.

Purdie J. D. and Doull K. M., 1964. - Supplementary feeding of honeybees on a pollen deficient honeyflow. Aust. Beekeeper 66 : 78-81.

Rosov S. A., 1944. - Food consumption by bees. Bee World 25 : 94-95.

Standifer L. N., Moeller F. E., Kauffeld N. M., Herbert E. W., Herbert Jr. and Shimanuki H., 1978. - Supplemental feeding of honeybee colonies. U.S.D.A. Agr. Inf. Bull. No. 413.

Todd F. E. and Vansell G., 1942. - Pollen grains in nectar and honey. J. econ. Ent. 35: 728-31. 